\title{
O MANDADO DE INJUNÇÃO À LUZ DAS TEORIAS DAS LUTAS POR RECONHECIMENTO DAS COMUNIDADES LGTBQ+
}

\author{
THE WRIT OF INJUNCTION IN THE LIGHT OF THE THEORIES OF \\ STRUGGLE FOR RECOGNITION OF THE LGTBQ+ COMMUNITY
}

\author{
Felipe Freitas de Araújo Alves ${ }^{\mathrm{I}}$ \\ Ana Patricia Ribeiro Approbato ${ }^{\mathrm{II}}$ \\ Maria Cristina Vidotte Blanco Tarrega ${ }^{\text {III }}$
}

${ }^{\mathrm{I}}$ Universidade de Ribeirão Preto,

Ribeirão Preto, SP, Brasil. Mestrado em

Direitos Coletivos e Cidadania. E-mail: felipe.jhs@hotmail.com

II Universidade de Ribeirão Preto,

Ribeirão Preto, SP, Brasil. Direitos

Coletivos e Cidadania. E-mail: patricia. apra@gmail.com

III Universidade de Ribeirão Preto, Ribeirão Preto, SP, Brasil. Doutora em Direito Empresarial. E-mail: mcvidotte@ uol.com.br

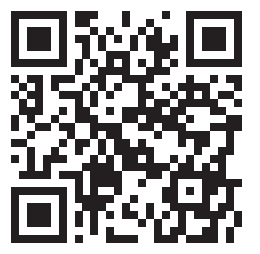

DOI: http://dx.doi.org/10.31512/rdj.v21i40.410

Recebido em: 16.03.2020

Aceito em: 18.07.2020
Resumo: Transcorridos mais de 30 anos da promulgação da Constituição Federal de 1988, faz-se necessária a análise de um dos instrumentos capazes de combater a inconstitucionalidade por omissão do legislador, qual seja: o mandado de injunção. Diante da crise político-representativa e financeira dos poderes da República vivenciada no país e da já propagada morosidade no processo de criaçáo de leis, além do descrédito em razão dos sucessivos escândalos perante a sociedade, o Judiciário passou a se destacar na garantia e provisão dos direitos fundamentais para com a coletividade, adotando uma postura mais ativista tendo em vista a inércia do Legislativo, e, também, do Executivo, participando de forma mais ampla e proativa na concretização dos valores e fins constitucionais. Entre as questôes alçadas ao Supremo Tribunal Federal, partindo-se do pressuposto de ser matéria disciplinada por norma constitucional, está o caso do julgamento do MI no 4733-DF, no qual se apreciou a existência de omissáo inconstitucional do Congresso Nacional em criminalizar a homofobia e a transfobia. Na ocasiāo ficou firmada a aplicabilidade subsidiária da lei que define os crimes resultantes de preconceito de raça ou de cor para esse fim. Neste contexto serão utilizadas pesquisas bibliográficas, documentais e qualitativas, além do método dedutivo, para analisar o Mandado de Injunção como instrumento institucional, à luz da teoria da luta por reconhecimento de Axel Honneth, componente contemporâneo essencial do conceito jurídico e filosófico do princípio da igualdade, bem como a sua aptidão para efetivar a proteção à auto-realização e à busca do direto à concreção da cidadania da população LGBTQ+.

Palavras-chave: Mandado de Injunção. Omissóes Inconstitucionais. Direitos Coletivos. Reconhecimento das comunidades LGBTQ+. 


\begin{abstract}
More than 30 years after the promulgation of the 1988 Federal Constitution, it is ever more necessary to analyze the writ of injunction as one of the instruments capable of combating unconstitutionality due to legislative omission. With the political-representative and financial crisis of the Republic's branches experienced in the country, and the well-known slowness of the process of law creation, as well as the discredit due to successive scandals before society, the Judiciary began to stand out in the guarantee and provision of fundamental rights for the collectivity. In this scenario, the Judiciary has adopted a more active stance due to the inertia of the Legislative and the Executive branches and has participated more broadly and proactively to insure the realization of constitutional values and objectives. Among the issues raised by the Federal Supreme Court, with grounds on the assumption that it is a matter discipled by constitutional norm, there is the case of ruling of the writ of injunction MI no 4733-DF. In this case, an evaluation of the existence of unconstitutional omission by the National Congress in criminalizing homophobia and transphobia was held. At the time, an understanding was reached to resort, in this case, to a subsidiary applicability of the law that defines crimes resulting from prejudice of race or color. In this context, bibliographical, documentary and qualitative research were used, in addition to the deductive method, to analyze the Writ of Injunction as an institutional instrument, in light of the theory of struggle for recognition by Axel Honneth, an essential contemporary component of the legal and philosophical concept of the principle of equality. This theoretical framework is also essential due to its ability to effectuate the protection of self-realization and the search for the right to concretize citizenship of the LGBTQ+ population.
\end{abstract}

Keywords: Writ of Injunction. Unconstitutional Omissions. Collective Rights. Recognition. LGBTQ+ Community.

\title{
1 INTRODUÇÃo
}

A Constituição da República Federativa do Brasil de 1988 representa uma conquista da sociedade brasileira, inaugurando o período democrático no país. Constituída por um rol de direitos e garantias fundamentais, com o intuito de normatizá-los, ela delegou esta atividade ao Poder Legislativo. Ocorre que quando há a omissão do poder legiferante é possível se socorrer de um remédio constitucional denominado mandado de injunção. Ele se encontra insculpido no artigo. $5^{\circ}$, inciso LXXI, da Constituiçáo da República Federativa do Brasil de 1988. Previsto como o instrumento adequado para sanar ausência de norma regulamentadora que inviabilize o exercício dos direitos e liberdades constitucionais, assim como as prerrogativas inerentes à 
nacionalidade, à soberania e à cidadania ${ }^{1}$. Em linhas gerais, norma constitucional de eficácia limitada é não autoaplicável, que demanda regulamentação por meio de lei e, que, portanto, depende do legislador ordinário para lhe conferir executoriedade plena, mediante integração da legislação. Dentre esses "tipos de normas" temos as programáticas, as quais estabelecem programas constitucionais de ação social a serem desenvolvidos mediante açáo integrada dos Poderes públicos instituídos. Em defesa da aplicabilidade dessas normas, Canotilho assegura "Às normas programáticas, é reconhecido hoje um valor jurídico constitucionalmente idêntico aos dos restantes preceitos da Constituição". (CANOTILHO, 1989, p.132)

Com a promulgação da Carta Magna, prevaleceu no Supremo Tribunal Federal o entendimento de que o Mandado de Injunção tinha por finalidade apenas reconhecer a inércia do legislador na regulamentação das normas programáticas, determinando o saneamento dessa omissão. No curso da história, objetivando a promoção da liberdade e da efetiva igualdade, o Tribunal Constitucional evocou para si o dever de concretizar o desejo do constituinte originário, o qual não estava sendo atendido somente pelo mero apelo pela purgação da mora legislativa do ente omisso (ENTERRIA, 1988). Diante das fortes críticas da doutrina, a Corte passou a adotar a tese concretista e, com isso, editar o regulamento faltante viabilizando o exercício dos direitos e liberdades que a Constituição buscou preservar. Esta mudança de paradigma se deu em 2007, no julgamento de três Mandados de Injunção que buscavam assegurar o direito de greve do servidor público.

A adoção desta nova postura, resultou em um posicionamento concretizador exarado no seio da decisão proferida no Mandado de Injunção $4733 \mathrm{DF}$, na mesma linha pontuada na ADO 26. Ao requerimento de reconhecimento de que a homofobia ${ }^{2}$ e a transfobia ${ }^{3}$ se enquadram no conceito de racismo ou, subsidiariamente, que sejam entendidas como discriminaçóes atentatórias a direitos e liberdades fundamentais, respondeu o Supremo com imediata implementação do exercício do direito até que sobrevenha norma regulamentadora. Esse novo entendimento da Corte Máxima demonstra aos poderes constituídos legiferantes que devem estar atentos às lutas por redistribuição e reconhecimento, objeto de estudo de Nancy Fraser (2008) e Axel Honneth (2015) como garantia de participação das minorias na vida social, sobretudo para promover a efetividade da Carta Política.

\section{EVOLUÇÃO E ASPECTOS CONCEITUAIS DO MANDADO DE INJUNÇÃO}

Ainda que a efetividade constitucional não seja uma novidade, o mandado de injunção é tido pela doutrina como uma garantia inédita inserida na CRFB, tendo em vista o histórico

1 Art. 5ㅇ, LXXI - conceder-se-á mandado de injunção sempre que a falta de norma regulamentadora torne inviável o exercício dos direitos e liberdades constitucionais e das prerrogativas inerentes à nacionalidade, à soberania e à cidadania.

2 "Rejeição ou aversão a homossexual e à homossexualidade". Houaiss Eletrônico. Versão assinante UOL

3 "Sentimento de aversão a ou discriminação e preconceito contra transgêneros e transexuais". Houaiss Eletrônico. Versão assinante UOL. 
constitucional brasileiro, conforme aponta Castro e Ferreira (2016). Afirmam ainda que a utilização de normas de eficácia limitada nas constituiçôes não é uma exclusividade nacional.

Castro e Ferreira (apud BARBOSA, 1932) ainda explicam já se haver notado que o constitucionalista estadunidense Thomas W. Cooley distinguira as normas constitucionais em autoexecutáveis (self executing provisions) das normas não auto executáveis (no self executing provisions) na Carta Magna americana de 1880. Para Ramos e Lima (2011), o mandado de injunçáo é inspirado no modelo anglo-saxônico, o qual foi transladado na Carta Magna de 1988.

Na versão brasileira, aquele que se sinta ameaçado, pode recorrer ao Judiciário em busca do saneamento da omissão legislativa, na forma do artigo $5^{\circ}$, inciso, LXXI, que apresenta o seguinte comando: "conceder-se-á mandado de injunçáo sempre que falta de norma regulamentadora torne inviável o exercício dos direitos e liberdades constitucionais e das prerrogativas inerentes à nacionalidade, à soberania e à cidadania.”

Inicialmente, o Supremo Tribunal Federal, através de seu relator Ministro Moreira Alves, respondeu ao desafio proposto pelo Mandado de Injunçáo 107-QO, que tratou da estabilidade do servidor público militar (art. 42, $\$ 9^{\circ}$, da CRFB), reconhecendo a eficácia plena e aplicabilidade imediata do mandado de injunção. Contudo, seguiria o rito do mandado de segurança (art. 24, parágrafo único, da Lei no 8.038/1990), até a edição da norma regulamentadora específica (OLIVEIRA, 1988).

Contudo, conforme observa Menezes (2015), as duas primeiras décadas, desde a vigência da CRFB/88, a Corte Suprema limitou-se, em sede de mandado de injunção, a somente declarar a inércia legislativa do Estado Legislador competente para editar a lei faltante, em face de omissão normativa inconstitucional. $\mathrm{O}$ fundamento da preservação da separação dos poderes, era visto pela doutrina como de (auto)contençáo pelo STF, o que evitava a invasão do Judiciário na esfera de atribuiçôes do Legislativo, acabou por esvaziar o instituto. Dessa forma, o postulante não alcançaria qualquer efeito concreto, resultado digno de críticas pela doutrina, posto que redundou na perda da efetividade prática do writ (BARROSO, 1993).

A evolução histórica do instituto fez com que o Supremo percebesse ser ineficiente apelar, tão somente, para a purgação da mora, uma vez que não surtia efeitos na prática, razão pela qual, segundo Dimoulis et al (2013, p. 86), também entenderam ser ineficaz a estipulação de prazo para atuação do ente em mora legislativa. ${ }^{4}$ Em 2006, na decisão do MI no 712/PA, tratando do direito de greve dos funcionários públicos, sob a relatoria do Ministro Eros Grau, a Corte superou aquele entendimento inicial e passou a adotar uma posição de concreção para suprir a omissão por meio da criação de norma específica a fim de assegurar a satisfação dos direitos negligenciados pelo legislador.

4 Cf. SUPREMO TRIBUNAL FEDERAL, Mandado de Injunção no 283, Relator Ministro Sepúlveda Pertence; Mandado de Injunção 284, relator Ministro Celso de Mello; Mandado de Injunção 232, relator Ministro Moreira Alves. 
A regulamentação na esfera infraconstitucional do mandado de injunção apenas ocorreu em 2016, com a a promulgação da Lei 13.300. Notadamente, essa lei inovou no seu artigo $2^{\circ} \mathrm{e}$ trouxe a omissão parcial ou total, ao dispor que:

Conceder-se-á mandado de injunção sempre que a falta total ou parcial de norma regulamentadora torne inviável o exercício dos direitos e liberdades constitucionais e das prerrogativas inerentes à nacionalidade, à soberania e à cidadania.

Parágrafo único. Considera-se parcial a regulamentação quando forem insuficientes as normas editadas pelo órgão legislador competente.

Para Castro e Ferreira (2016), André Ramos Tavares leciona que se pode afirmar ter se consolidado o entendimento de que uso do mandado de injunçáo condicionava-se à verificaçáo do nexo de causalidade entre o direito fundamental e a necessidade de expediçáo da norma integrativa regulamentadora parcial ou total.

\section{LEGITIMAÇÁO E PROCEDIMENTO}

O direito de ação do mandado de injunção se alinha ao regramento comum, segundo o qual a legitimação ad causam decorre da necessidade de pertinência subjetiva, em razão da titularidade do direito afirmado na demanda, sempre satisfazendo os pressupostos processuais, como a petição inicial atendendo os requisitos do artigo 319 do Código de Processo Civil. ${ }^{5}$

A Lei 13.300 indica, em seu artigo $3^{\circ}$, os legitimados ativos para impetrar o writ constitucional: pessoas naturais ou jurídicas, com a exceção das pessoas jurídicas de direito privado, que se afirmam titulares dos direitos, das liberdades ou das prerrogativas inerentes à nacionalidade, à soberania e à cidadania. No que tange à legitimação passiva, consoante o artigo $3^{\circ}$, "são os poderes, órgãos ou autoridades com atribuição para editar a norma regulamentadora". Os legitimados, em lista taxativa, para propor o mandado de injunção coletivo está prevista no artigo 12 da Lei 13.300/2016, desde que em defesa dos direitos, das liberdades e das prerrogativas a serem protegidos pelo mandado de injunção coletivo pertencentes, indistintamente, "a uma coletividade indeterminada de pessoas ou determinada por grupo, classe ou categoria”.

$\mathrm{O}$ artigo $4^{\circ}$ dessa mesma lei, disciplina a petição inicial, seus requisitos e prazos a qual deve ser instruída com a identificação do órgão impetrado e a pessoa jurídica que ele integra ou a qual encontra-se vinculado. Além dos aspectos a serem observados na petiçáo inicial, a referida lei traz o rito a ser seguido por partes e autoridades, a exemplo do artigo $7^{\circ}$ que trata da presença do Ministério Público na qualidade de fiscal da ordem jurídica. Nos feitos propostos pelo Parquet, a sua intervenção como custos legis tornar-se-á prescindível, em razão do princípio da unidade institucional estampado no $\$ 1^{\circ}$ do art. 127 da CRFB/88, refletido também no art. $4^{\circ}$ da Recomendação CNMP no 34/2016.

5 BRASIL. Lei no 13.105/2015, institui o Código de Processo Civil. Disponível em: http://www.planalto.gov.br/ ccivil_03/_ato2015-2018/2015/lei/113105.htm. Acesso em: 12.07.2019. 


\section{TEORIAS SOBRE OS EFEITOS DO MANDADO DE INJUNÇÃO}

A pretensão do mandado de injunção é declarar a inconstitucionalidade por omissão, bem como a normatização de um direito subjetivo constitucional, mediante a fixação de um prazo e em caso de concessão da ordem, a implementação desse direito. Note-se que, em sendo indicada uma solução normativa na sentença, podem dar ensejo, em relação aos efeitos subjetivos, limitados (interpartes), a exemplo dos MI no 788-8/DF e 1083/DF, ou extensivo (erga omnes), como nos MI no 670/ES e 708/DF. A partir de 2008, o STF vem alternando entre a adoçáo de duas teorias envolvendo os efeitos da coisa julgada no mandado de injunção: da resolutividade e da independência jurisdicional.

A teoria da resolutividade está explicitada nas palavras de Bernardo Gonçalves Fernandes (2017, pp. 632 e 633):

A sentença do mandado de injunção produz a norma para o caso concreto com natureza constitutiva interpartes, viabilizando o direito de forma imediata à luz da própria exegese do art. 50, LXXI, da CR/88, que preleciona a concessão da injunção justamente para viabilizar direitos inviabilizados por falta de norma regulamenta $\mathrm{d}$ ora de norma constitucional, ocorrendo, portanto, uma "atividade integradora do Poder Judiciário.

Sobre a teoria da independência jurisdicional, Fernandes complementa, "nesta, a sentença do mandado de injunção possui caráter constitutivo erga omnes, cabendo, portanto, ao Poder Judiciário editar a norma geral se estendendo de forma abstrata a todos, inclusive a aqueles que não pleitearam a tutela”.

Ao longo de três décadas, pode-se perceber a evolução jurisprudencial que formaram as correntes no Supremo Tribunal Federal em decorrência da promulgação da Carta Magna de 1988, como explicitou o Ministro Néri da Silveira, na Ata da 7a sessão extraordinária realizada em 16 de março de 1995:

Há, como sabemos, na Corte, no julgamento dos mandados de injunçấo, três correntes: a majoritária, que se formou a partir do Mandado de Injunção 107, que entende deva o Supremo Tribunal Federal, em reconhecendo a existência mora do Congresso Nacional, comunicar a existência dessa omissão, para que o Poder Legislativo elabore a lei. Outra corrente, minoritária, reconhecendo também a mora do Congresso Nacional, decide; desde logo, o pedido do requerente do mandado de injunção e provê sobre o exercício do direito constitucionalmente previsto. Por último, registro minha posição, que é isolada: partilho do entendimento de que o Congresso Nacional é que deve elaborar a lei, mas também tenho presente que a Constituição, por via do mandado de injunção. quer assegurar aos cidadáos o exercício de direitos e liberdades, contemplados na Carta Política, mas dependentes de regulamentaçấo. Adoto a posição que considero 'intermediária'. Entendendo que se deva, também, em primeiro lugar, comunicar ao Congresso Nacional a omissão inconstitucional, para que ele, exercitando sua competência, faça a lei indispensável ao exercício constitucionalmente assegurado aos cidadãos. Compreendendo, entretanto, que, se o Congresso Nacional não fizer a lei, em certo prazo que se estabeleceria na decisão, o Supremo Tribunal Federal pode tomar conhecimento de reclamaçáo da parte, quanto ao prosseguimento da omissão, e, a seguir, dispor a respeito do direito 'in: concreto[...]. 
Em síntese, tais entendimentos adotados pelo STF foram bem resumidos por Alexandre de Morais como sendo: a) tese náo concretista e b) tese concretista, subdividida em geral e individual, ainda subdividida em direta e intermediária. ${ }^{6}$

\section{TEORIA DO RECONHECIMENTO E A DECISÁO DO STF NO MANDADO DE INJUNÇÃO 4377/DF}

A Associação Brasileira de Gays, Lésbicas e Transgêneros -ABGLT, requereu em sede de mandado de injunção coletivo, no ano de 2012, a criminalização específica de todas as formas de homofobia e transfobia, especialmente com relação às ofensas individuais e coletivas, dos homicídios, das agressóes, ameaças e discriminaçóes motivadas pela orientação sexual e/ou identidade de gênero, real ou suposta, da vítima com base na parte final artigo $5^{\circ}$, inciso LXXI, da CRFB/88 com o intuito de obter a viabilização do exercício de cidadania da população LGBTQ+ brasileira, bem como de seu direito fundamental à segurança.

A tese defendida na peça em comento, buscou fundamento no artigo constitucional já citado, o que permitiu que o mandado de injunção fosse impetrado objetivando a criminalização específica das condutas de homofobia e transfobia, pelo fato de impedirem o exercício das prerrogativas inerentes à cidadania das vítimas em questão. Para tanto, se utilizaram da interpretação da norma originária que afirma que "conceder-se-á mandado de injunção sempre que a falta total ou parcial de norma regulamentadora torne inviável o exercício dos direitos e liberdades constitucionais e das prerrogativas inerentes à nacionalidade, à soberania e à cidadania”. Buscou-se o reconhecimento de que a falta da norma criminal regulamentadora torna inviável o exercício de direitos e liberdades constitucionais, adicionadas às prerrogativas inerentes à cidadania da população LGBTQ+, no passado e ainda hoje. São do Grupo Gay da $\mathrm{Bahia}^{7}$, os relatórios e estatísticas usados para fundamentar a tese, naquele momento, devido ao fato de não haver dados oficiais disponibilizados, apesar da sistematização desses ser uma das metas do Plano Nacional de Direitos Humanos, n. $3^{\circ} .^{8}$

Tal demanda gira em torno da Lei 7.716/89 que não traz em seu bojo, de forma expressa, a previsão para a puniçấo de condutas homofóbicas e transfóbicas. Segundo a doutrina e jurisprudência majoritária, o rol do artigo 20 deste diploma é taxativo, criminalizando somente as condutas resultantes de preconceito de raça ou de cor. ${ }^{9}$ Por outro lado, a mora do Congresso Nacional em votar projetos de lei, com o intuito de ampliar o rol de condutas criminosas, incluindo a homofobia e transfobia, deixa a população LGBTQ+ sem a adequada proteção

6 MORAES, Alexandre de. Direito constitucional. 13. ed. São Paulo: Atlas, 2003.

7 Disponível em: https://homofobiamata.wordpress.com/estatisticas/assassinatos-2012/. Acesso 10 set. 2019.

8 BRASIL. Decreto 7.037 de 21 de dez de 2009. Aprova o Programa Nacional de Direitos Humanos - PNDH-3 e dá outras providências. Disponível em http://www.planalto.gov.br/ccivil_03/_ato2007-2010/2009/decreto/ d7037.htm

9 STF. 1 Turma . Inq 3590/DF, relator Ministro Marco Aurélio, julgado em 12. ago. 2014. 
estatal, exposta à açôes de caráter segregacionista, além de negar-lhes o reconhecimento da legitimidade de sua existência.

Nesta ocasião, o Supremo Tribunal Federal decidiu, por maioria, a procedência do mandado de injunção a fim de se reconhecer a mora inconstitucional do Congresso Nacional, bem como pela aplicação da Lei 7.716/89, com efeitos prospectivos, até que o Congresso Nacional delibere sobre o tema, estendendo a tipificaçáo prevista para os crimes resultantes de discriminaçáo ou preconceito de raça, cor, etnia, religiáo ou procedência nacional à discriminaçáo sexual ou identidade de gênero. E é justamente nesse ponto, que a teoria política vai ao encontro do direito.

Em decorrência dessa decisão, podemos traçar um paralelo com a teoria do reconhecimento de Axel Honneth, a qual objetiva compreender as situaçóes sociais de desigualdade, opressão, injustiça e desrespeito, de modo que se possa ir além de diagnóstico de fenômenos sociais negativos em determinadas condições históricas, como também identificar soluções práticas para a superação desses problemas.

Segundo Honneth, é possível, a partir do conceito de reconhecimento, numa reconstrução da argumentação de Hegel, distinguir três formas de reconhecimento: o amor, o direito e a solidariedade (HONNETH, 2008, p. 23). Por outro lado, as mudanças sociais podem ser explicadas por meio de uma dinâmica de desrespeito. Nesse sentido, leciona Rúrion Melo (2014, pp. 17 a 36) que o amor, "se abala por maus tratos e violação que ameaçam a integridade física e psíquica" que acomete um grupo; o direito, ao ser atingido por "privação de direitos e exclusão, que atingem a integridade social do indivíduo como membro de uma comunidade político-jurídica" e a solidariedade, posta em cheque por "degradaçáo e ofensas, que afetam os sentimentos de honra e dignidade do indivíduo como membro de uma comunidade cultural de valores". O desrespeito a qualquer uma delas implica no abalo da auto realização da pessoa, privando-a do reconhecimento de determinadas facetas de sua identidade. $\mathrm{Na}$ busca por restabelecer tais condiçóes intersubjetivas de auto realização, práticas de reconhecimento institucionalizadas, encontramos casos como o do Mandado de Injunção no 4733/DF, sendo uma luta que tem o papel de conscientização das vulnerabilidades mútuas.

Ainda nesse aspecto, o Estado não deve ser entendido como um organismo independente e exterior ao indivíduo. O Estado é o indivíduo. É no seio do Estado que o sujeito adquire o reconhecimento mútuo e a sua liberdade. A luta emancipatória se dá no contexto das relações cotidianas, não sendo mais uma teoria somente voltada a intelectuais, pois o reconhecimento surge na formação da possibilidade de alguém ter sua identidade e anseios completados. Esta completude depende crucialmente da autoconfiança (amor), do auto respeito (direito) e da autoestima (solidariedade).

Esta teoria do reconhecimento é criticada por Nancy Fraser, que se opóe ao paradigma identitário. Para ela, esta perspectiva da centralidade da identidade e autor realização carece de um critério distintivo pelo qual não seria qualquer reivindicação a ser defendida. Já na teoria do 
reconhecimento de Honneth, seria possível legitimar anseios como extremismo, neonazismo e terrorismo a fim de se garantir a auto realizaçâo.

Ela propóe que a luta pelo reconhecimento seja travada em dimensóes apartadas, como na distribuição (de recursos produtivos e de renda), no reconhecimento (das contribuiçôes variadas dos diferentes grupos sociais) e na representação (na linguagem e em todo o domínio do simbólico).

O STF ao fundamentar a decisão prolatada no bojo do mandado de injunção supracitado, sob as premissas de que a existência de qualquer tipo de discriminação, inclusive a que se fundamenta na orientação sexual das pessoas ou em sua identidade de gênero se constitui ato atentatório ao Estado Democrático de Direito, tendo em vista que o direito à igualdade sem discriminaçôes abrange identidade ou expressão de gênero e a orientaçáo sexual. Este reconhecimento da omissão legislativa em tipificar a discriminação por orientação sexual ou identidade de gênero foi dado em consonância com os tratados internacionais ratificados pelo Brasil, bem como por que se erige da leitura do texto da CRFB/88, um mandado de criminalização relativo a toda e qualquer forma de discriminação atentatória dos direitos e liberdades fundamentais e em razão da intolerância ao sofrimento causado em decorrência desta.

$\mathrm{Na}$ base constitucional da decisão, firmou-se o direito à dignidade (art. $1^{\circ}$, III, da CRFB); o direito à igualdade (art. 5०, caput, da CRFB/88); a garantia constitucional do mandado de injunção (art. 50, LXXI da CRFB/88); e o mandado constitucional de criminalização contra qualquer discriminação atentatória dos direitos e liberdades fundamentais (art. 5º, XLI, da $\mathrm{CRFB} / 88$ ); seguido pela base convencional (art. $5^{\circ}, \$ 2^{\circ}$, da $\mathrm{CRFB} / 88$ ): o direito à igualdade (art. 24 do Pacto Internacional de Direitos Civis e Políticos); a proibição contra a discriminação (art. 40 da Convenção para Eliminação da Discriminação Racial e art. 20 do Pacto Internacional de Direitos Civis e Políticos).

O entendimento foi construído a partir de respeitável doutrina, entre elas, João Francisco da Fonseca em “Processo do Mandado de Injunção”; André de Carvalho Ramos em “Mandados expressos de criminalização no direito internacional dos direitos humanos" e Luis Roberto Barroso em "A Dignidade da Pessoa Humana no Direito Constitucional Contemporâneo", bem como em precedentes, notadamente, os que formam jurisprudência do Excelso Tribunal, da Corte Interamericana de Direitos Humanos, entre outras organizaçóes de proteção da pessoa humana, a exemplo do constante do MI 642, de relatoria do Ministro Celso se Mello; o Relatório Violência contra Pessoas Lésbicas, Gays, Bissexuais, Trans e Intersex nas Américas da Comissão Interamericana de Direitos Humanos.

O enfeixar de todo esse arcabouço jurídico, aliado à perspectiva de que a injustiça sofrida por gays e lésbicas é basicamente uma questáo de reconhecimento ao que leciona Nancy Fraser (2001, pp. 257 a 258), "Ao terem sua sexualidade desacreditada, os homossexuais estáo sujeitos à vergonha, molestação, discriminação e violência, enquanto lhe são negados direitos legais e proteção igual - todas negações fundamentais do reconhecimento" terminou por culminar 
com mais uma decisáo concretista do STF ao reconhecer a mora inconstitucional do Congresso Nacional e aplicar a Lei 7.716/89, até que o Congresso Nacional legisle a respeito, para a tipificação prevista para crimes resultantes de discriminação e preconceito de raça, cor, etnia, religião ou procedência nacional à discriminação por orientação sexual ou identidade de gênero.

Nesta perspectiva de uma postura substancialista do STF, Oliveira e Silveira (2013) afirmam que a jurisdição constitucional intervém de forma a defender os direitos das minorias contra os arbítrios das maiorias contempladas no processo político de formação e concreção do Direito.

\section{CONSIDERAÇÓES FINAIS}

Ao longo dos trinta anos da promulgação da Constituição da República Federativa do Brasil, em 1988, assistiu-se à evolução do instituto do mandado de injunçáo, desde a sua fase inicial, marcada pelo acolhimento da tese não concretista, meramente declaratória, até a consolidação de sua natureza normativo concretizadora, para reconhecer e conceder a prestação jurisdicional adequada, com a consequente efetivaçáo dos direitos fundamentais do impetrante.

O processo hermenêutico sofrido pelo mandado de injunçáo neste período, acrescido da positivaçáo oriunda da Lei 13.300/16, protagonizado pelo Supremo Tribunal Federal, mostrouse profícuo, devido ao aumento do acesso aos direitos e prerrogativas constitucionais. Contudo, resta muito a fazer, tendo em vista que muitos direitos definidos na Carta Magna carecem de regulamentação pelo Legislativo.

Pode-se afirmar que o Constituinte Originário concedeu ao Judiciário, através do mandado de injunção, as ferramentas necessárias para dar proteção e materialidade aos direitos e liberdades constitucionais, sanando a mora legislativa, pelo que exerce seu papel de guardião das promessas sociais contidas na Constituição Federal.

Neste diapasão, a conduta ativa do Judiciário não se consubstancia em desrespeito ao princípio da separação de poderes, tendo em vista ter recebido do poder constituinte esta árdua missão de colmatar as lacunas, não ocupadas pelos demais Poderes, através do remédio constitucional em comento.

Ocorre que, no recente entendimento perfilhado no MI 4733/DF, o Excelso Supremo Tribunal admitiu (i) a mora inconstitucional do Congresso Nacional e determinou (ii) a aplicação da Lei 7.716/89, até que o Congresso Nacional legisle a respeito, para a tipificação prevista para crimes resultantes de discriminação e preconceito de raça, cor, etnia, religiáo ou procedência nacional à discriminação por orientação sexual ou identidade de gênero.

Neste contexto, conclui-se pela importância da adesão do STF à teoria do reconhecimento de Honneth ou Fraser, pois a concreção dos direitos fundamentais da população LGBTQ+ foi obtida a partir do início da cura da injustiça cultural a que estavam sujeitos. Dito isto, é mister 
que haja uma reavaliação das identidades desrespeitadas, dos grupos marginalizados, superando a homofobia e o sexismo, partindo-se para a valorização positiva da diversidade cultural, único caminho para obtenção de justiça e cidadania para todos.

\section{REFERÊNCIAS}

BARROSO, Luís Roberto. Mandado de injunção: perfil doutrinário e evoluçáo jurisprudencial. Revista de Direito Administrativo, Rio de Janeiro, v. 191, p. 1-13, jan./mar. 1993. Disponível em:http://bibliotecadigital.fgv.br/ojs/index.php/rda/article/ view/45637/47410. Acesso em: 12 set. 2019.

BRASIL. Conselho Nacional do Ministério Público. Recomendaçáo no. 34/2016. Disponível em: https://www.cnmp.mp.br/portal/images/rec_34.pdf. Acesso em 12.07.2019.

BRASIL. Constituição da República Federativa do Brasil de 1988. Disponível em: http://www.planalto.gov.br/ccivil_03/constituicao/constituicaocompilado.htm. Acesso em: 12.07.2019.

BRASIL. Decreto 7.037 de 21 de dez de 2009. Aprova o Programa Nacional de Direitos Humanos - PNDH-3 e dá outras providências. Disponível em http://www.planalto.gov.br/ ccivil_03/_ato2007-2010/2009/decreto/d7037.htm

BRASIL. Lei no 13.105/2015, institui o Código de Processo Civil. Disponível em: http:// www.planalto.gov.br/ccivil_03/_ato2015-2018/2015/lei/113105.htm. Acesso em: 12.07.2019.

BRASIL. Supremo Tribunal Federal. Mandado de injunçáo n. 788-8/DF. Impetrante: Maria Aparecida Caetano Lenarduzzi. Impetrado: Presidente da República. Relator: Min. Carlos Britto. Diário da Justiça Eletrônico, Brasília, 8 maio 2009. Disponível em: http://redir.stf.jus. br/paginadorpub/paginador.jspdocTP=AC\&docID=591237. Acesso em: 10 set. 2019.

BRASIL. Supremo Tribunal Federal. Mandado de injunção n. 1.083/DF. Impetrante: Manoel Baía Campos. Impetrado: Presidente da República. Relator: Min. Marco Aurélio. Diário da Justiça Eletrônico, Brasília, 3 set. 2010. Disponível em: http://redir.stf.jus.br/ paginadorpub/paginador.jsp?docTP=AC\&docID=613863. Acesso em: 10 set. 2019.

BRASIL. Supremo Tribunal Federal. Mandado de injunção n. 708/DF. Impetrante: Sindicato dos Trabalhadores em Educação do Município de João Pessoa - SIMTEM. Impetrado: Congresso Nacional. Relator: Min. Gilmar Mendes. Diário da Justiça Eletrônico, Brasília, 31 out. 2008c. Disponível em http://redir.stf.jus.br/paginadorpub/paginador. jsp?docTP=AC\&docID=558551. Acesso em: 10 set. 2019.

BRASIL. Supremo Tribunal Federal. Mandado de injunção n. 670/ES. Impetrante: Sindicato dos Servidores Policiais Civis do Estado do Espírito Santo - SINDPOL. Impetrado: Congresso Nacional. Relator: Min. Mauricio Corrêa. Diário da Justiça Eletrônico, 
Brasília, 31 out. 2008b. Disponível em: http://redir.stf.jus.br/paginadorpub/paginador. jsp?docTP=AC\&docID=558549. Acesso em: 10 set. 2019.

CANOTILHO, José Joaquim. Direito Constitucional e Teoria da Constituiçáo. Coimbra: Almedina, 1999.

CASTRO, Guilherme de Siqueira; FERREIRA, Olavo Augusto Vianna Alves. Mandado de Injunção. Salvador: Juspodivm, 2016. 176 p.

COSTA, Eduardo José da Fonseca. As noçóes jurídicas - processuais de eficácia, efetividade e eficiência. Revista de Processo, São Paulo: RT, v. 121, mar. 2005.

DIMOULIS. Dimitri et al. Resiliência Constitucional. 1 ed. São Paulo: Direito GV, 2013

ENTERRIA, Eduardo Garcia de. La constituición como norma y el Tribunal

Constitucional. Madrid: Civitas, 1988.

FERNANDES, Bernardo Gonçalves. Curso de Direito Constitucional. 9 ed. Salvador: Juspodivm, 2017.

FRASER, Nancy. "Da redistribuiçáo ao reconhecimento? Dilemas da justiça na era pós-socialista”, em SOUZA, Jessé (org.) Democracia hoje: novos desafios para a teoria democrática contemporânea. Brasília: Editora UnB. 2001. p. 257-258.

HONNETH. Axel. Luta por reconhecimento: a gramática moral dos conflitos sociais. São Paulo: 34.2003

HOUAIS ELETRÔNICO. Versão Assinante UOL.

KRELL, Andreas J. Direitos sociais e controle judicial no Brasil e na Alemanha: os descaminhos de um direito constitucional “comparado”. Porto Alegre: Sergio Antonio Fabris Editor, 2002.

LIMA, Martonio Mont'Alverne Barreto; OLIVEIRA, Marcelo Andrade Cattoni de; STRECK, Lenio Luiz. A nova perspectiva do Supremo Tribunal Federal sobre o controle difuso: mutaçáo constitucional e limites da legitimidade da jurisdiçáo constitucional. Disponível em: http://seer.uenp.edu.br/index.php/argumenta/article/view/72/72. Acesso em: 06.06.2019.

MARIN, Eriberto Francisco Bevilaqua; BEZERRA, Pedro Henrique Araújo de Alvarenga. Mandado de injunçáo e sentimento constitucional. Revista de Informação Legislativa: RIL, v. 55, n. 219, p. 53-73, jul./set. 2018. Disponível em: http://www12.senado.leg.br/ril/ edicoes/55/219/ril_v55_n219_p53. Acesso em 09 set 2019.

MELO, Rúrion. Da teoria à práxis? Axel Honneth e as lutas por reconhecimento na teoria política contemporânea. Rev. Bras. Ciênc. Polít., Brasília, n. 15, p. 17-36, Dec. 2014. Available from http://www.scielo.br/scielo.php?script=sci_arttext\&pid=S010333522014000300017\&lng=en\&nrm=iso. Acesso em 29 abr. 2019 
MENDES, Gilmar Ferreira; Paulo Gustavo Gonet Branco. Curso de Direito Constitucional. 12a ed. Sáo Paulo: Saraiva, 2017.

MENDES, Gilmar. Mandado de Injunção. Revista Direito Público, São Paulo, v. 5, n. 19, p.126-148, jan/fev 2008. Disponível em: https:/www.portaldeperiodicos.idp.edu.br/ direitopublico/article/view/1286/753. Acesso em: 04 set. 2019.

MENDES, Gilmar Ferreira. O mandado de injunçáo e a necessidade de sua regulaçáo legislativa. Revista Jurídica da Presidência, Brasília, v. 13, n. 100, p. 165-192, jul./set. 2011. Disponível em: https://revistajuridica.presidencia.gov.br/index.php/saj/article/view/134/126. Acesso em: 10 set. 2019.

MENEZES, Bruno Paiva. ATIVISMO JUDICIAL: o Supremo Tribunal Federal estaria legislando? Caso dos mandados de injunçáo que regulamentam o direito de greve dos servidores públicos. Disponível: em: http://bd.camara.leg.br/bd/handle/bdcamara/13716. Acesso em 07. Set. 2019.

MORAES, Alexandre de. Direito constitucional. 13. ed. São Paulo: Atlas, 2003.

MOREIRA, Barbosa. Conteúdo e efeitos da sentença: variaçóes sobre o tema. In: Temas de direito processual: quarta série. São Paulo: Saraiva, 1989.

OLIVEIRA, Herzeleide Maria Fernandes. O mandado de Injunção. Revista de Informação Legislativa, Brasília, v. 25, n. 100, p. 47-62, out./dez. 1988, 10/1988. Disponível em: https:// www2.senado.leg.br/bdsf/handle/id/181881. Acesso em 08 set 2019.

OLIVEIRA, Rafael Tomaz de; SILVEIRA, Ricardo dos Reis. A Jurisdição Constitucional para além do mito do legislador negativo: concreçáo do projeto constitucional e cidadania no estado democrático de direito. Paradigma, Ribeirão Preto, n. 22, p.2-26, jan/dez 2013. Disponível em: http://revistas.unaerp.br/paradigma/article/view/301/324. Acesso em: 07 set. 2019.

RAMOS, Paulo Roberto Barbosa; LIMA, Diogo Diniz. Mandado de Injunçáo: Origem e Perspectivas. Revista de Informação Legislativa, Brasília, v. 48, n. 191, p. 27-38, jul./set. 2011. Disponível em: https://www2.senado.leg.br/bdsf/item/id/242906. Acesso em 05 set 2019.

SILVA, Diogo Barbosa e. As potencialidades do mandado de injunção: o controle integral das omissóes inconstitucionais. 2017. 159 f. Dissertação (Mestrado) - Curso de Mestrado em Direito, Universidade Federal da Bahia, Salvador, 2017. Disponível em: http://bdtd.ibict.br/ vufind/Record/UFBA-2_dd6a8766c1e2b06245503748b8cebaf0. Acesso em: 04 ago. 2019.

SILVA, José Afonso da. Proteçáo constitucional dos direitos humanos no Brasil: evoluçáo histórica e direito atual. Revista da Procuradoria Geral do Estado de Sáo Paulo. Edição especial em comemoração aos 10 anos da Constituição Federal. Ed. Setembro de 1998.

SIQUEIRA, Guilherme de Castro; FERREIRA, Olavo Augusto Vianna Alves. Mandado de Injunção. Salvador: Juspodivm, 2016, p. 176. 